Cronfa - Swansea University Open Access Repository

This is an author produced version of a paper published in :

Race \& Class

Cronfa URL for this paper:

http://cronfa.swan.ac.uk/Record/cronfa33860

\title{
Paper:
}

Burnett, J. (2015). The war on welfare and the war on asylum. Race \& Class, 57(2), 96-100. http://dx.doi.org/10.1177/0306396815595919

This article is brought to you by Swansea University. Any person downloading material is agreeing to abide by the terms of the repository licence. Authors are personally responsible for adhering to publisher restrictions or conditions. When uploading content they are required to comply with their publisher agreement and the SHERPA RoMEO database to judge whether or not it is copyright safe to add this version of the paper to this repository. http://www.swansea.ac.uk/iss/researchsupport/cronfa-support/ 


\section{The war on welfare and the war on asylum}

The war on welfare claimants, ramped up over the last few years, is, with a Conservative victory, now set to intensify. The next phase of UK Chancellor George Osborne's 'deficit reduction plan' has already begun. ${ }^{1}$ And although $£ 12$ billion more cuts to the welfare budget are, as I write, yet to be announced, the impact already on disabled people, the young, those with mental health needs and the poor gives a flavour of what is to follow.

In 2014 the Department for Work and Pensions (DWP) considered using a legal loophole to avoid publishing the results of its secret reviews into benefit-related deaths. That it did so indicates the extent to which this is a war that suppresses the unpleasant truths about its welfare 'reforms'. Yet this can already be measured through assiduous documenting of its impacts. It can be measured through the return of diseases 'common in the Victorian era' $^{2}$ such as rickets, malnutrition and gout, and by an epidemic of self-harm. It can be measured by way of evictions, by the social cleansing of the poor ${ }^{3}$ and by rocketing levels of homelessness. The experiences of Titina Nzolameso ${ }^{4}$ - recently reunited with her family after being decanted from London, falling into homelessness and having her children taken into care - indicate how the most punitive welfare measures, whilst classbased, are impacting disproportionately on minorities, including black families. Defended by its purveyors, the war on welfare is experienced as a form of structured violence. And the more it is, the more it mirrors the government's parallel 'war' on asylum.

\section{Categorising and punishing the poor}

These parallel 'wars', of course, have their own histories, their own targets and their own trajectories. The rationales on which they are based are not the same - despite similarities in the way the state wages them. But, like the war on asylum, the war on welfare is given legitimacy by relentless propaganda campaigns portraying its targets as pariahs. It is driven by the spurious categorisation of people as 'genuine' or 'bogus'. And the latter are to be punished.

The machinery implicated in this is vast, and it is expanding. As with asylum, the welfare regime systemically creates its own deviance as 'claimants' are befuddled by labyrinthine processes set up to produce failure. Administered behind closed doors, these processes rarely face scrutiny. But, occasionally, the manner in which they operate is fleetingly exposed. The revelations, two years ago, that job centre staff were rewarded with chocolate treats for implementing the strictest sanctioning regimes ${ }^{5}$ highlighted a callous 
disregard for suffering. The revelations last year that UK Border Agency staff were incentivised with cash vouchers to refuse asylum seekers' appeals highlighted a casual culture of cruelty. ${ }^{6}$

Whilst these perks are certainly not the main drivers behind these systems of control, they are symptomatic of the manner in which both the welfare and asylum systems, ostensibly dealing in preserving lives, have reduced lives to statistics. The processing of poverty, illness and desperation is now a well-established source of revenue for private companies competing for contracts. And the figures are well known. They include the $£ 500$ million awarded to Maximus to carry out work capability assessments after French firm Atos ended early its contract of around the same value. They include the asylum housing contract awarded in 2012 to Serco, G4S and Clearel which could be potentially worth $£ 1.8$ billion over seven years. ${ }^{7}$ And they include the lucrative contracts to run immigration removal centres such as the $£ 180$ million awarded to Mitie to merge Harmondsworth and Colnbrook. These tenders may differ, but one thing unites them: the costs are public, the profits are private.

\section{Policy transfer and governance of the poor}

In academic terminology, the manner in which a state learns from within itself (and from others) is often called policy transfer. ${ }^{8}$ But as aspects of the parallel wars on asylum and welfare mirror each other it is not so much policy that is being transferred, as the expertise and techniques deployed in order to control and in some cases inflict pain on specific sections of the population. When the Work and Pensions Secretary Iain Duncan Smith reinvigorated plans in 2014 to deny cash to benefits claimants with 'destructive habits' (such as drug or alcohol addiction, or debt) ${ }^{9}$ - instead forcing people to rely on prepaid cards redeemable only for certain items - he drew on myths of a feckless poor that go back centuries. These myths, self-righteous and condescending, are at the heart of the current swathe of welfare 'reforms'. And yet they are actualised in plans for a pre-paid card system which has direct parallels with those already given to certain 'refused' asylum seekers. The implications for those surviving on these cards are well known: ${ }^{10}$ they stigmatise; they restrict movement as they cannot be used for travel; they often fail to work; they make it difficult to save for essential items such as shoes and they ultimately intensify the impact of poverty. But this is the point. Just as with asylum seekers, the aim is not so much to support as to deter. The message is that it is not the system that has failed, but the individual. 
Of course, what this does is deflect attention from state policies and practices which create poverty and a degrading asylum system. But in the process, an increasingly wide range of professions are drawn in to the governance of the poor, and in some cases perverted as they do so. The plans in the Conservative manifesto to remove or reduce support from those benefits claimants who do not take up a 'recommended treatment' ${ }^{11}$ provide a green light for those medical or psychological professionals circling for contracts. They continue an enthusiasm for outsourcing that has seen cognitive behavioural therapy applied to benefits claimants ${ }^{12}$ and psychometric tests carried out on jobseekers, ${ }^{13}$ alongside the use of healthcare professionals to decide who is 'fit to work'. And substitute the phrase 'fit to work' with the term 'fit to fly' and the same principle is applied in the asylum system particularly in immigration removal centres - on an equally ubiquitous basis. The loyalty that many of these outsourced medical services operating in immigration detention appear to hold is not first to their 'patients', but to the imperatives of immigration control. As with that deployed to fulfil the more coercive aims of the welfare system, what this amounts to, ultimately, is a betrayal of the stated purpose of the profession. And such is the pervasiveness of administering 'healthcare' in a way that ensures people can be removed from the country - sometimes in direct contradiction to their actual medical needs - that one medical professional created a term for it: 'repatriation medicine'. ${ }^{14}$

\section{The 'secret penal system'}

What all of these things point to, though, are not just systems of processing that mirror each other, not just perversions of professions from care to control, and not just the state transfer of techniques to deal with groups of people. They also point to the construction of parallel justice systems in welfare and asylum existing alongside the criminal justice system.

The academic David Webster calls the sanctioning regime that has accelerated over the last few years - to the point that more sanctions are applied to benefit claimants than there are fines issued by the courts - a 'secret penal system'. ${ }^{15}$ This version of justice, where decisions about a person's life are often made in absentia, punishes the most banal of transgressions such as missing appointments. It is armour-plated, with an appeals process that cannot always be accessed. It acts as a de facto form of surveillance; it operates on the basis of fear and it exacerbates mental health problems. Practically unaccountable, it shares all of these things with an asylum system which frequently causes terror amongst its applicants, humiliates those who come into contact with it, tears families apart and has 
a prison system of its own. There are, of course, differences. But one thing that unites both is the state-sanctioned use of poverty as a weapon.

Hundreds of thousands of asylum seekers have been forced into destitution since those whose claims are refused started being made homeless in 2002. As with parts of the welfare system, which increasingly operate on the basis of coercion in order to enforce compliance, this is a form of absolute poverty which is used punitively to serve as an example for others. And in this disturbed morality, what is encouraged is not sympathy with the people who suffer, but empathy with the system that creates the suffering. It is this inverted morality that links the 'benefit fraud hotline', first established in 1996 but placed at the centre of the Conservatives' benefit reforms in 2011, and the 'immigration crime hotline' established soon after (in 2012). Both are ineffective in their stated terms (600 calls a day to the former and 100 a day to the latter yield few 'results'); both exist as vehicles for malicious, unfounded accusations that can be made with no risk of comeback. But this is beside the point. Both ensure that their respective target communities know they live under permanent surveillance. They elevate snooping to a public virtue. They turn neighbour against neighbour. And they ask us to have blind faith in systems which routinely inflict harm upon those they come into contact with. They seek to make immigration and welfare officers of us all.

\section{References}

Elliott Larry 'Fresh spending squeeze has already begun, says George Osborne', The Guardian

1. (20 May2015), available at: http://www.theguardian.com/business/2015/may/20/fresh-spendingsqueeze-has-already-begun-says-george-osborne. Google Scholar

John Middleton, 'Why we should be concerned about the return of Victorian diseases', The

2. Guardian (8August 2014), available at: http://www.theguardian.com/healthcarenetwork/2014/aug/08/return-victorian-diseases-gout-tb-measles-malnutrition. Google Scholar

Daniel Douglas, 'Over 50,000 families shipped out of London boroughs in the past three years due to welfare cuts and soaring rents', The Independent (29 April 2015), available

3. at: http://www.independent.co.uk/news/uk/home-news/over-50000-families-shipped-out-oflondon-in-the-past-three-years-due-to-welfare-cuts-and-soaring-rents-10213854.html. Google Scholar

Gentleman Amelia, 'Family reunited after housing battle led to homelessness and separation', The 4. Guardian (20 May 2015), available at: http://www.theguardian.com/society/2015/may/20/familyreunited-housing-battle-separation-benefits-cap. Google Scholar 
Wintour Patrick, 'Labour demands action over jobcentre targets', The Guardian (22 March 2013),

5. available online at: <http://www.theguardian.com/society/2013/mar/22/labour-demands-actionjobcentre-targets $>$. Google Scholar

Taylor Diane, Mason Rowena, 'Home Office staff rewarded with gift vouchers for fighting off

6. asylum cases', The Guardian (14 January 2014), available at: http://www.theguardian.com/uknews/2014/jan/14/home-office-asylum-seekers-gift-vouchers. Google Scholar

7. 'Sheffield, Leeds, Stockton: G4S asylum tenants speak out against overcrowding and WIN!', Symaag (9June 2015), available at: http://www.symaag.org.uk/category/g4s/.

8. Ibid.

'Duncan Smith outlines plans for prepaid benefits cards in place of cash', The Guardian

9. (29 September2014), available at: http://www.theguardian.com/politics/2014/sep/29/duncansmith-prepaid-benefits-cards-cash-payments.

10. 'The Azure card report - a life without cash for asylum seekers', British Red Cross, available at: http://www.redcross.org.uk/en/About-us/Advocacy/Refugees/Azure-payment-card.

Conservatives Manifesto, 'Strong leadership, a clear economic plan, a brighter, more secure

11. future', Conservatives (2015), available at: https://s3-eu-west-

1.amazonaws.com/manifesto2015/ConservativeManifesto2015.pdf. Google Scholar

Stratton Allegra, 'Jobless to be offered "talking treatment" to help put Britain back to work', The

12. Guardian (4 December 2009), available

at: http://www.theguardian.com/society/2009/dec/04/jobless-therapy-talking-cbt-

unemployment. Google Scholar

Malik Shiv, 'Jobseekers' psychometric test "is a failure", The Guardian (6 May 2013), available

13. at: http://www.theguardian.com/society/2013/may/06/jobseekers-psychometric-test-

failure. Google Scholar

14. Burnett Jon, 'Repatriation medicine', Criminal Justice Matters (Vol. 82, no. 1, 2010). Google Scholar

Webster David, 'Benefit sanctions: Britain's secret penal system', Centre for Crime and Justice 15. Studies (26 January 2015), available at: http://www.crimeandjustice.org.uk/resources/benefitsanctions-britains-secret-penal-system. Google Scholar

Jon Burnett is assistant editor of IRR News and carries out research into racial violence, domestic race policy in the UK and the economics of migration. A version of this was first published on IRR News in May 2015. 